University of Michigan Law School

University of Michigan Law School Scholarship Repository

\title{
Liberalism Stumbles in Tennessee
}

Donald J. Herzog

University of Michigan Law School, dherzog@umich.edu

Available at: https://repository.law.umich.edu/reviews/7

Follow this and additional works at: https://repository.law.umich.edu/reviews

Part of the Legal History Commons, Litigation Commons, and the Religion Law Commons

\section{Recommended Citation}

Herzog, Donald J. "Liberalism Stumbles in Tennessee." Review of Summer for the Gods: The Scopes Trial and America's Continuing Debate Over Science and Religion, by E. J. Larson. Mich. L. Rev. 96, no. 6 (1998): 1898-909.

This Review is brought to you for free and open access by the Faculty Scholarship at University of Michigan Law School Scholarship Repository. It has been accepted for inclusion in Reviews by an authorized administrator of University of Michigan Law School Scholarship Repository. For more information, please contact mlaw.repository@umich.edu. 


\title{
LIBERALISM STUMBLES IN TENNESSEE
}

\author{
Don Herzog*
}

Summer for the Gods: The Scopes Trial and America's Continuing Debate Over Science and Religion. By Edward J. Larson. New York: Basic Books. 1997. Pp. 336. \$25.

The Scopes trial will never be the same. I mean the trial immortalized in Inherit the Wind, ${ }^{1}$ with its Southerners clutching in vain to their cozy scientific illiteracy and mechanically literal faith in the Bible, its idiotic intolerant Southerners destined to fall to the gale winds of modernity, liberalism, secularism, and skepticism embodied by a heroic ACLU and the inimitable Clarence Darrow. So what if Scopes got convicted? Surely the trial made a laughingstock of everything Tennessee stood for in banning the teaching of evolution from the public schools. And in a touch worthy of a gruesome morality play, William Jennings Bryan, a bloated buffoon skewered by Darrow on the stand, staggered off to die five days later. For a very long time now, we've been invited to think of the Scopes trial as a last gasp of illiberal stupidity before the inexorable march of civil liberties and modern science.

You don't have to know a great deal about the trial itself to surmise that something is misfiring badly in this triumphalist history. For one thing, the fundamentalists allegedly dispatched in those sleepy Tennessee hills seem to be doing rather nicely, thank you very much. Crusades against teaching evolution in public schools - and for teaching that curious creature, neither fish nor fowl, dubbed "creation science" - seem to be sweeping the nation. The ACLU has fallen on hard times. Recall George Bush sneering, in his most majestically nasal manner, that Michael Dukakis had dared to confess - to publicly confess! - that he was "a cardcarrying member of the ACLU." And the enchanting likes of William Kunstler, Johnnie Cochran, and Alan Dershowitz make it hard to feel unconditionally fond of Darrow's public success. If liberalism and the rest are destined to triumph, they sure seem to be taking their sweet time about it. Could it be a case of the tortoise and the hare?

The real story of the Scopes trial, it turns out, is more interesting, more mischievous, and more perverse than the complacent re-

* Professor of Law and Professor of Political Science, University of Michigan. A.B. 1978, Cornell; A.M. 1980, Ph.D. 1982, Harvard. — Ed.

1. INHERIT THE WIND (United Artists 1960). 
ceived wisdom. A historian of science and a lawyer, Professor Larson $^{2}$ has written a devastatingly good book, Summer for the Gods. I found myself wishing only that his legal and political analysis were more sharply etched.

\section{The TRIAL's Background}

Larson sets the stage for the farcical trial with a quick review of evolution's state of play in the scientific community at the time. The names come a bit fast and furious and some of the analytic points are slightly blurry. But careful readers will note the key distinction. There was in fact quite widespread agreement among scientists on the fact of evolution, understood as change in species over time. But there were heated disagreements on what causal mechanism best explained the fact. Natural selection, firmly installed only after the neo-Darwinian synthesis of the 1940s, was one contender among others, and the evidence for it was not overwhelming. ${ }^{3}$

Christian theologians, meanwhile, disagreed on what to make of the scientific findings. Some, who became known as fundamentalists, insisted on the literal truth of the Biblical account. Many found natural selection threatening not just because it seemed to undercut Genesis, but because it cast nature as cruel. Worse, it strongly suggested atheism: what benevolent God would leave his creation floundering helplessly in the clutches of such ruthlessly impersonal mechanisms? Others, however, worried that it discredited religion to insist on a six-day creation: the fossil record seemed to tell a different story. (Larson notes the impact of the discovery of Piltdown man in England; only hundreds of pages later does he remind the reader in passing that that was a hoax.4) Some of these socalled modernists were happy to interpret Scripture more creatively. Perhaps the days of creation were each vastly long periods of time. Or perhaps there was a gap in the account. Other theologians were willing to grant the evolution of all the lower animals but held out for the special divine creation of man.

Against this backdrop, William Jennings Bryan launched the fateful last campaign of a remarkable political life. The campaign would overshadow his runs for the Presidency and his stint as Wilson's Secretary of State, which ended when Bryan resigned rather

2. Professor of History and Law, University of Georgia.

3. See generally William Provine, The Evolutionary Synthesis: Perspectives on THE UNIFICATION OF BIOL.OGY (1980).

4. Pp. 11-13 (noting discovery), 250 (noting in passing its discrediting as a hoax). I should note that Larson briefly notes that "Piltdown man later lost his place in the human family tree...." P. 8. 
than participate in the conduct of World War I.5 Bryan wanted evolution out of the public schools. A fundamentalist himself, he was no political or legal dummy. His dominant argument, in keeping with the populist democracy he had always defended, was that surely the taxpayers of a state had a right to tell their employees, the public school teachers, what they could and could not teach. Claiming, perfectly plausibly, that a large majority of Americans opposed the teaching of evolution, Bryan insisted that they were entitled to have their legislatures pass the appropriate statutes.

It's glib, surely, to say that this rationale for keeping evolution out of the public schools is a mere pretext for forwarding an aggressively religious agenda. Sometimes it is, sometimes it isn't. We don't routinely describe people who do want evolution taught in the public schools as "obviously" or "genuinely" motivated by crassly anticlerical sentiments; we don't mock their official commitments to teaching science as a fig leaf covering their illicit desire to smash organized religion.

Bryan, along with more ferocious fundamentalists such as Billy Sunday, assisted the people, lobbying the Tennessee legislature. Bryan, however, didn't want a genuine criminal statute passed; he seems to have thought that a law with no penalties attached would do the trick (p. 47). But this sorcerer's apprentice was not fully in control of the movement he helped summon. Moving quickly, the Tennessee legislature considered a proposal that it be "a misdemeanor, punishable by a maximum fine of $\$ 500$, for a public school teacher 'to teach any theory that denies the story of the Divine Creation of man as taught in the Bible, and to teach instead that man had descended from a lower order of animal." "6 The act was passed and duly signed by the governor.

Some contemporary critics bemoaned, in triumphalist terms, the proposal the legislature passed: "The quicker this jackass measure is booted into a waste basket," opined one state newspaper, "the better for the cause of enlightenment and progress in Tennessee." Larson himself steers clear of the assumption that science and liberalism represent progress against benighted religion. (This is true for the most part, anyway. He does permit himself an occasional sneer, like the one he lobs at today's Bryan College and its creationist science education: "With Bryan College faculty overseeing the town's portrayal of the Scopes trial, [Bryan] and his ideas still

5. LaWrence W. LeVIne, Defender of the Fatth: William Jennings Bryan: The LAST DECADE, 1915-1925 (1965) remains the standard treatment of the closing chapters of Bryan's career.

6. P. 50 (quoting 1925 Tenn. House Bill 185).

7. P. 52 (quoting Monkey Business, Rockwood Times, reprinted in State Press Comment, KNOXVILle Journal, Feb. 11, 1925, at 6). 
get a fair hearing in Dayton."8) But the way he frames the debate, familiar enough in liberal theory, is inapposite. From chapter headings to sections to paragraphs to sentences, Larson invites us to see a conflict between majoritarian democracy, represented by Bryan, and individual rights, represented by the ACLU. That's sensible, I think, only as long as we rivet our attention on the rights of the poor schoolteacher committed to evolution, but gagged by an insensitive state legislature from conveying his beliefs. But this picture begs one crucial question after another. What is the scope of the teacher's putative right? And what is its justification? Surely schoolteachers may not blather on about whatever they like, but may be required to teach a state-imposed curriculum. (If the eighth grade teacher is fired for constantly discussing popular music or his social life or Sumerian artifacts, we don't think his rights of free speech have been violated. We think he's an irresponsible boor and applaud the board of education powerful enough to sack the resident clowns on their faculty.) Is the state required to stipulate that the schools teach only scientifically reputable theories of creation? (It may be politically tempting to hand this hot potato off to the community of natural scientists, those imposing cultural figures of expertise, but does that make it obligatory? Isn't a legislature that claims not just that it's wise to dodge responsibility, but that they're required to, engaged in massive bad faith?) What about the rights of taxpayers? Or the rights of parents to shape or even control what their children are exposed to?

A characteristically discreet historian, Larson doesn't want to dig in and defend his views on these questions. I confess I have never fully understood this professional norm. Larson's commitments here unequivocally shape the story he is telling. Without sustained defense, they look a bit like covert editorializing.

\section{LANDING IN DAYTON}

The narrative pace quickens splendidly when Larson lands in Dayton, home of the Scopes trial, and drily reveals how the trial came to pass. Larson knows a good yarn when he sees one, and here, I think, he's right to get out of the way of his material; only his compressed ironic tone reminds the reader that these facts didn't magically organize themselves, but the tale is being artfully sculpted.

Seeking to challenge the Tennessee statute, the ACLU issued a press release. "We are looking for a Tennessee teacher who is willing to accept our services in testing this law in the courts. . . O Our lawyers think a friendly test case can be arranged without costing a

8. P. 264; see also p. 32. 
teacher his or her job." The path from the publication of this release in the Chattanooga Times to the Scopes trial is not shrouded in myth, but the historical evidence is not utterly reliable either. The best bet seems to be that a small group hanging out in a local drugstore saw in the release an opportunity for bringing Dayton publicity - and money. They rounded up John Scopes, a twentyfour-year-old football coach who taught natural sciences and math, and Sue Hicks (male), one of the city attorneys and a close friend of Scopes. Hicks, inclined to doubt the constitutionality of the statute, recalled that after being told of the scheme, "Scopes said he would be glad to do it, and I said I wouldn't mind to prosecute him."10 Hicks then went through the motions of securing a warrant for Scopes's arrest and serving it, after which the amiably cooperative criminal defendant wandered off to play tennis (p. 91). The sheer weirdness of this cozy arrangement was underlined by the newspaper report that the prosecution was acting "under the auspices" of the ACLU, "which, it is said, has offered to defray the expenses of such litigation."11

Dayton poised itself for an army of well-heeled tourists with money falling out of their pockets. That army turned out to be depressingly small, at least for the boosters who had hoped to cash in on the extravaganza. But the national news media did descend in force, sending out millions of words by newly installed telegraph wires that ran right into the courtroom; one enterprising Chicago radio station arranged for a live telephone feed to broadcast the proceedings (pp. 140-42). The circus triggered anxieties about the collapse of the overcrowded courthouse and forced special preparations and construction - the town's first airstrip was installed, enabling camera footage to be flown out (p. 140). In keeping with the conspicuous lack of animosity toward the criminal defendant, though, the townspeople, no angry rednecks, managed to charm curmudgeonly H.L. Mencken and were cordial to Clarence Darrow (pp. 93, 136).

Still, no one would mistake Dayton for an island of secular humanism in an ocean of Tennessee religiosity. Indeed, religion had quite a presence even in court. The courthouse itself sported a large sign instructing passersby to "READ YOUR BIBLE" (p. 140). The Scopes trial judge was fond of opening each day's session with prayer from a local clergyman: not perfunctory prayers, but long combative ones, usually aimed aggressively at the defense. (Dar-

9. P. 83 (quoting Plan Assault on State Law on Evolution, Chattanooga Dallx Times, May 4, 1925, at 5).

10. P. 91 (quoting Juanita Glenn, Judge Still Recalls Monkey Trial - 50 Years Later, KNOXVILLE JOURNAL, July 11,1975 , at 17 ).

11. P. 92 (quoting Arrest Under Evolution Law, NAshville Banner, May 6, 1925, at 1). 
row tried in vain to get the judge to drop this routine (p. 158).) In response to continued complaints from the defense team, though, the judge did permit a local association of ministers to choose who would offer the prayers each session, and they dutifully alternated between modernist and fundamentalist preachers (p. 167). (I suppose this was "neutral" on the controversies raging within the Christian theological community, but obviously not on the matters dividing Bryan and Darrow.) One Sunday morning at the beginning of the trial, Bryan served as preacher in a local Methodist church - and the judge and his family sat in the front pew (p. 157). And at one point during the trial, when Darrow apologized to avoid a contempt citation, the judge burst out into an epiphany: "We forgive him ... and we command him to go back home and live in his heart the words of the Man who said: 'If you thirst come unto Me and I will give thee life" " (p. 186). If there were pressing issues here about the appearance of justice, they sailed past the judge.

\section{TrIaL Tactics}

Larson is distressingly brief in his presentation of Darrow's defense strategy. Maybe Basic Books, Larson's publisher, doesn't want to bore its readers with the ins and outs of legal argument, but they are indispensable both to following the story and understanding how its most memorable moment - Darrow's examination of William Jennings Bryan - came to take place. But Larson does report the nub of the matter. Darrow and his fellow defense attorneys - fancy ACLU lawyers and a disheveled, dissolute local first tried to argue that the statute was unconstitutional on its face. The federal Bill of Rights had not yet been incorporated into the Fourteenth Amendment and thus did not apply to the states. So the defense turned to the Tennessee state Constitution. There they found "express guarantees of individual freedom of speech and religion, requirements for clearly understandable indictments and titles for legislation, and a clause directing the legislature to cherish science and education" (pp. 158-59). I would imagine that this last clause had no more legal force than the preamble of the federal Constitution. Regardless, Darrow unburdened himself of one of his riveting speeches. The judge was unmoved.

Forced, then, to try the case on the merits, the defense wanted to bring in a stream of experts to demonstrate the width and depth of the scientific consensus on evolution. Their theory seems to have been that the sloppily worded statute required the jury to decide the relationship between evolution and Genesis. Recall the statute's wording, forbidding the teaching of "any theory that denies the story of the Divine Creation of man as taught in the Bible, and to teach instead that man had descended from a lower order of 
animal" (p. 50). If my conjectural reconstruction of Larson's compressed account is right, the defense argued that since the conjunction "and" joined the statute's two clauses, as an elementary matter of statutory construction this was a crime of two elements. Teaching evolution - a theory that "man had descended from a lower order of animal" - was no violation unless evolution denied the story of Genesis. And since plenty of modernist theologians insisted the two were fully compatible, the court could not conclude otherwise as a matter of law. Again, though, the judge was unmoved. He announced that the defense could not introduce any expert testimony (p. 180).

This left the defense stymied. After some procedural sparring about how they might enter into the record some version of what their expert witnesses would have said, they threw in the towel. In fact, as the trial wound down, they would urge the jury to convict their client, though without formally pleading guilty, so as to preserve their rights on appeal (p. 191). But first, Darrow cooked up one satanically clever blow.

\section{ONE LAST BLow}

Virtually no one knew what was coming when they filed into court, expecting the case to close. After the judge permitted the defense to enter into the record a brief compendium of what their experts were going to say, Darrow had the delicious audacity to call William Jennings Bryan to the stand. The prosecution, eager throughout to confine the case to the relatively narrow question of a public employee who had violated the terms of his contract, tried to avoid the coming fiasco. But Bryan wouldn't be dissuaded, lest anyone say he had spurned the opportunity to do battle with the forces of godlessness. "They did not come here to try this case," he observed with some plausibility. "They came here to try revealed religion. I am here to defend it, and they can ask me any questions they please."12

So Darrow - that notoriously good litigator, mocking, angry, and supercilious by turns - assaulted poor Bryan with the timehonored artillery of the village atheist. Had Jonah really lived inside a whale? Had Joshua stopped the sun? The litany took its toll, not just on the sweaty Bryan but on fundamentalist religion. At least a dozen times, the prosecution tried to get this decidedly unhelpful witness off the stand. What, they demanded, was the evidentiary point of this line of questioning? Darrow's answer: "We have the purpose of preventing bigots and ignoramuses from con-

12. P. 187 (quoting Trial Transcript at 288). 
trolling the education of the United States . . . and that is all."13 One needn't be an evidence scholar to wonder about that rationale. But Bryan vehemently insisted on continuing. "I am simply trying to protect the word of God against the greatest atheist or agnostic in the United States," he fumed. ${ }^{14}$ The judge, moved perhaps by courtly Southern etiquette or by a misbegotten sense of Christian charity, ruled that "[t]o stop it now would not be just to Mr. Bryan."15 So the torture continued, for two excruciating hours, at which point the same judge's ineffable sense of justice dictated that enough was enough.

\section{QUANDARIES IN LEgaL ETHICS}

Poor Scopes really was a mere vehicle, and not just because he faced a friendly prosecution designed to test a statute. The statute itself was a vehicle or pretext. For the combat waged in Tennessee in the summer of 1925 was freighted with huge political significance. What were the respective claims of science and religion? On what terms could Christian fundamentalists participate in the nation's public life, in its public schools and other institutions? The trial was a stage for the pursuit of such lofty questions.

That, of course, was why the news media descended in force. So Larson thinks when, invoking a threadbare trope that always makes me shudder in dismay, he writes, "[p]owerful social forces converged on Dayton that summer: populist majoritarianism and traditional evangelical faith versus scientific secularism and modern concepts of individual liberty" (p. 83). A causal gloss on this language seems most straightforward. More illuminating, I think, would be shifting from cause and effect to the language of meaning. The trial meant what it did because of the contexts supplied by the background of majoritarianism and the rest.

The trial's meaning presented the players - the judge, the defense attorneys, even the prosecution - with some very difficult questions about how to conduct the case. For this trial was fought not just before a quirky judge and a Tennessee jury, but before the proverbial court of public opinion. We can't, I think, take it for granted that it was incumbent on the players simply to shut their eyes to that larger realm. That view might seem most plausible in the case of the judge. For instance, if in his considered judgment Darrow's questioning Bryan was inadmissible under the rules of evidence, one might find it hard to see how the judge could justify admitting it anyway on the basis that the radio audience in Chicago

13. P. 6 (quoting Trial Transcript at 284-304).

14. P. 190 (quoting Trial Transcript at 299).

15. P. 5 (quoting Trial Transcript at 284-304). 
was hanging on every word - or even on the basis that his courtroom could help assist a broader public debate on hotly contested matters. (Imagine a judge who, worried about the democratic credentials of law, took pride in flouting settled legal rules to promote public deliberation.) But suppose the judge pondered the age-old maxim that justice must be done and must be seen to be done. Suppose he was aware that the general public, hanging on every word but oblivious to the fine points of the law, would scream in outrage as he made a procedurally correct ruling. Must he damn the torpedoes?

Now consider the defense attorneys. An advocate's sole duty, we ordinarily think, is to do his best job, within the rules, to secure the acquittal of his client. Is that true in a case like this? Remember the bizarrely playful inception of this prosecution; remember that no one ever thought Scopes was in serious danger. (A gentlemanly Bryan offered to pay his fine (p. 129).) An easy way out of the complexities here would be to say that it's permissible for the advocate to take steps that might not serve his client's interests if and only if he has the informed consent of his client. I think it's too easy, actually, but that's a story for another day. In any event, nowhere does Larson suggest that Darrow had any such consent from Scopes.

Perhaps Darrow believed that skewering Bryan on the stand and fulminating about the illicit desires of ignorant bigots to control public education would somehow serve Scopes. Suppose he believed it would assist Scopes on appeal, not for any sound legal reasons, but because higher courts would find themselves politically ashamed of upholding his conviction. Or perhaps he believed it couldn't materially harm Scopes and was independently worth doing. And what kind of harm is relevant here? Suppose it wouldn't bear on Scopes's odds of prevailing on appeal, but it would help brand him as a notorious public figure for the rest of his life in ways Scopes did in fact find objectionable (p. 201) and could or should have been reasonably presumed to find objectionable. Suppose these considerations diverge, so that increasing his odds of prevailing on appeal also help make him a notorious public figure. Can all these considerations be fobbed off to the informed consent of the client?

\section{ANOTHER MORAL OF THE Story}

Larson closes his story by tracing the historiographical and political aftermath of the trial. He portrays the cold warriors who redescribed Bryan as the soul of un-American intolerance and the modern Christian conservatives who, perhaps keeping their distance from the trial, still are exercised by the teaching of evolution 
in public schools. I would add just one further context for making sense of it all.

Historically, liberals have taken two stances on religion. First, there are the fire-breathing anticlerical types who deride religion, especially Christianity. Theirs is the classic triumphalist script, of reason and Enlightenment sweeping away the mystified cobwebs of medieval religion. We usually associate this strand of the tradition with the French Enlightenment; recall the pleasant aspiration to strangle the last king with the guts of the last priest ${ }^{16}$ or the caustic ridicule punctuating Voltaire's Philosophical Dictionary. ${ }^{17}$ But it surfaces elsewhere in the tradition, too - in England with Hume's cheerfully secular antipuritanism and his Dialogues Concerning Natural Religion, an explosively sophisticated brief for atheism;:18 and in America with Paine ${ }^{19}$ and Jefferson. ${ }^{20}$

Second, there are those liberals patiently making the argument for religious toleration, careful not to express the slightest bit of disrespect for religion. Some may be opportunistically trading on contempt for the religious. But others surely are not. Some value what they see as the secular or political benefits of religion. Consider this bit of evidence for the thesis that American schools have been overrun by secular humanism: George Washington's Farewell Address, which we routinely celebrate for urging the merits of no entangling alliances with bellicose Europe, dwells at some length on the claim that the American republic will not in fact survive without widespread Christian commitment. According to Washington only a few minds - read: Jefferson - are capable of upright behavior absent belief in a Creator. ${ }^{21}$ Locke had a more elaborate version of the same view: the rational motivation for moral behavior was fear of hell. Atheists shouldn't be tolerated, not because of their religious error, but because they would not make reliable citizens. ${ }^{22}$ Others are themselves religiously devout and worry about Caesarism, the corruption suffered by religion that gets wrapped up in politics.

16. The origin of this sentiment seems to be 1 Jean Meslier, Testament ch. 2 ( $R$. Charles ed., 1864).

17. See Voltaire, Philosophical Dictionary (Theodore Besterman ed. \& trans., Penguin Books 1972) (1764).

18. See David Hume, The Natural History of Religion and Dlalogues Con. Cerning Natural Religion (A. Wayne Colver and John Valdimir Price eds. 1976) (1779).

19. See Thomas Paine, The age of Reason (1794).

20. See Thomas JefFerson, JefFerson's Extracts from the Gospels (Dickson W. Adams et al. eds., 1983); Isaac Kramnick and R. Lawrence Moore, THE GODLESs Constitution: The Case Against Religious Correctness 88-109 (1996).

21. See George Washington, Farewell Address, in A Compilation of the Messages and Papers of the Presidents, 1789-1897, at 213-24 (James D. Richardson ed., 1896).

22. For analysis of the relevant passages in Locke, see DON HERzog, WrrHout FoundaTIONS 87-105 (1985). 
Putting it crudely, then, liberals collectively send devout Christians two messages: "you're idiots" and "you're entitled to toleration." No wonder that so many Christians conflate the two strands of the liberal tradition and see liberal toleration as a dismissive gesture, something tantamount to, "oh, go and do whatever backwards things you like in private; just don't bother us here in important public settings." No wonder, too, that issues surrounding evolution, creation science, school prayer, and the like have been so hotly contested. In the ban that keeps creation science and prayer out of the public schools, some see evenhanded liberal toleration: the ban expresses no view on the merits of creation science and prayer; it says only that they don't belong in this social setting. Others see the ban as an official proclamation that secular humanism is better than Christianity.

This context illuminates a splendid irony of our day. Conservatives like to gnash their teeth about the inanities of so-called identity politics, which they see as a creature of the rabid left: gays, lesbians, feminists, members of allegedly benighted minority groups, all battle for public recognition as dignified equals. But shouldn't we see the campaigns for creation science and the like as identity politics, too? Aren't they symbolic campaigns for social status pursued by Christians who worry that they are becoming or already have become second-class citizens in a polity presided over by smug secular humanists?

Larson notes that the ACLU was uncomfortable with Darrow's role in the case and sought, unsuccessfully, to squeeze him out of the appeals process (pp. 207-10). Their worries seem to have been tactical. What Tennessee court, they wondered, would want to side with the man whose brutal trial examination had led to the death of the revered William Jennings Bryan? Maybe it is easy to say this in hindsight, but the ACLU should have been worried about a matter of political principle. The anticlerical strand of liberalism brashly insults the cherished beliefs of millions of Americans. This public denial of Christians' standing as fully dignified citizens is uncalled for. Unlike racists, for example, whom liberals appropriately assault, Christians offend no principle of liberal politics. One might argue that Christians tend to ally themselves with illiberal causes such as gay-bashing and antifeminism. In fact, though, political disagreements in the Christian tradition remain marvelously wide and deep. And even those who defend their illiberalism on recognizably Christian grounds supply liberals with no good reason for bashing Christianity. Here, liberals might learn a lesson from their alleged adversaries and remember to hate the sin but love the sinner. 
The public denial of Christians' standing as fully dignified citizens also has politically perverse consequences for liberals, making it utterly imprudent. I have absolutely nothing nice to say about creation science. But I wonder if we would be subjected to furious demands for its inclusion in public education, with all the ensuing political tension surrounding the separation of church and state, if American history were not so heavily peppered with Christianbashing. I don't want to overestimate the causal impact of Darrow's courtroom tactics. But they seem exemplary of a recurrent political stupidity liberals should have abandoned long ago. 